\title{
PUSAT PERAWATAN PSIKOLOGIS UNTUK PEKERJA DI LINGKUNGAN BISING - KAWASAN JABABEKA
}

\author{
Juan Vinandy¹), Suwandi Supatra ${ }^{2)}$ \\ 1)Program Studi S1 Arsitektur, Fakultas Teknik, Universitas Tarumanagara, Juanvinandy@gmail.com \\ 2) Program Studi S1 Arsitektur, Fakultas Teknik, Universitas Tarumanagara, suwandis@dtt.untar.ac.id
}

\begin{abstract}
Abstrak
Peningkatan industrialisasi saat ini tidak dapat dipisahkan dengan peningkatan teknologi modern. Pemanfaatan teknologi untuk mengatasi pekerjaan berat di berbagai sektor industri semakin maju dan jenis pekerjaan yang menggunakan kekuatan otot berangsur diganti dengan kekuatan mesin. Meskipun demikian pada berbagai industri belum pernah terjadi industri dengan otomasi sempurna (completely automated). Sebagai konsekuensinya adalah kegiatan manual di berbagai tempat kerja berdampingan dengan mesin industri masih banyak dilakukan. Nyatanya percepatan teknologi yang ada masih belum seimbang dengan kemampuan tenaga kerja yang menanganinya, sehingga peran Higiene perusahaan dan Kesehatan kerja (hiperkes) dan Keselamatan kerja sangat diperlukan didalamnya. Faktor lingkungan seperti kebisingan yaitu suara yang tidak harmonis dengan intensitas pada kejadian adalah salah satu faktor yang berpengaruh terhadap produktivitas pekerjaan. Dampak yang berpengaruh dari penggunaan mesin terhadap kesehatan pekerja adalah kebisingan yang mengakibatkan gangguan pada pendengaran (ketulian), gangguan psikologis (merasa tidak nyaman), gangguan fisiologis (peningkatan tekanan darah dan nadi). Arsitektur seharusnya dapat membantu dengan menghadirkan suatu bangunan yang berfungsi sebagai peningkatan kesehatan (promotif), pencegahan penyakit (preventif), penyembuhan penyakit (kuratif), dan pemulihan kesehatan (rehabilitatif). Penghadiran program dengan desain biofilik bertujuan untuk memberi bantuan kepada tenaga kerja, melindungi tenaga kerja dari gangguan kesehatan yang timbul dari pekerjaan dan lingkungan kerja, meningkatkan kesehatan, memberi pengobatan dan perawatan serta rehabilitas.
\end{abstract}

Kata kunci: kesehatan mental; pekerja pabrik ; psikologis.

\begin{abstract}
The increase in industrialization today cannot be separated from the improvement of modern technology. The mechanization of work in various industrial sectors is increasingly advanced and the types of work that use muscle strength have gradually been replaced by machine strength because they can cope with tough work. However, in many industries there has never been a completely automated industry. As a consequence, manual activities are still being carried out in various workplaces side by side with industrial machines. In fact, the acceleration of existing technology is still not balanced with the ability of the workforce to handle it, so the role of Hiperkes and Work Safety is needed in it. Environmental factors such as noise, namely the sound that is not harmonious with the intensity of the incident, is one of the factors that affect workers in doing work so that it will affect work productivity. The impact that affects the use of machines on the health of workers is noise which causes hearing loss (deafness), psychological disorders (feeling uncomfortable), physiological disorders (increased blood pressure and pulse). Architecture should be able to help by presenting a building that functions as health promotion (promotive), disease prevention (preventive), disease healing (curative), and health restoration (rehabilitative). The presence of a program with a bbiophilic design aims to provide assistance to workers, protect workers from health problems arising from work and the work environment, improve health, provide medication and care as well as rehabilitation.
\end{abstract}

Keywords: factory worker ; mental health ; psychological. 


\section{PENDAHULUAN}

\section{Latar Belakang}

Peningkatan industrialisasi saat ini tidak dapat dipisahkan dengan peningkatan teknologi modern. Pemanfaatan teknologi untuk mengatasi pekerjaan berat di berbagai sektor industri semakin maju dan jenis pekerjaan yang menggunakan kekuatan otot berangsur diganti dengan kekuatan mesin. Meskipun demikian pada berbagai industri belum pernah terjadi industri dengan otomasi sempurna (completely automated). Mahalnya peralatan otomasi, terbatasnya ruang kerja juga sumber daya manusia yang tersedia, maka penggunaan mesin sepenuhnya masih sangat sulit. Sebagai konsekuensinya adalah kegiatan manual di berbagai tempat kerja berdampingan dengan mesin industri masih banyak dilakukan.

Nyatanya percepatan teknologi yang ada masih belum seimbang dengan kemampuan tenaga kerja yang menanganinya, sehingga peran Higiene perusahaan dan Kesehatan kerja (Hiperkes) dan Keselamatan Kerja sangat diperlukan didalamnya (Suma'mur P.K, 1996). Faktor lingkungan seperti kebisingan yaitu suara yang tidak harmonis dengan intensitas pada kejadian adalah salah satu faktor yang berpengaruh terhadap produktivitas pekerjaan.

Di lingkungan kerja, kebisingan merupakan masalah kesehatan kerja yang selalu timbul, terutama pada sektor industri seperti pabrik. Berbagai penelitian terhadap kebisingan pada pekerja di sektor industri telah dilakukan yang menunjukkan bahwa kebisingan dapat menyebabkan penyakit pendengaran, psikologis maupun lainnya. Seperti penelitian yang telah dilakukan oleh (Wuladani et al, 2015) pada PT. Rahman Abdijaya periode Oktober 2013 September 2014, didapat $18 \%$ pekerja mengalami penurunan fungsi pendengaran. (Kurniawan et al, 2012) yang menyatakan bahwa terdapat hubungan yang signifikan antara paparan kebisingan dalam jangka waktu yang lama pada masinis UPT crew kereta api Solo Balapan Surakarta. Penelitian (Koagouw et al, 2013) juga mengungkapkan bahwa ada hubungan yang signifikan antara kebisingan dengan kesehatan pada pekerja bengkel las Kecamatan Mapanget Kota Menado. Faktanya menurut Organisasi Kesehatan Dunia (WHO), kebisingan adalah salah satu ancaman lingkungan yang paling berbahaya bagi kesehatan. Dan menurut Badan Lingkungan Eropa (European Environment Agency / EEA), kebisingan bertanggung jawab atas 16.600 kematian dini dan lebih dari 72.000 rawat inap setiap tahun di Eropa saja.

Dampak yang berpengaruh dari penggunaan mesin terhadap kesehatan pekerja adalah kebisingan yang mengakibatkan gangguan pada pendengaran (ketulian), gangguan psikologis (merasa tidak nyaman) dan gangguan fisiologis (peningkatan tekanan darah dan nadi). Dampak - dampak tersebut tentunya dapat menurunkan produktivitas para pekerja industri. Tidak hanya itu, kesehatan mental juga dapat memicu gangguan kesehatan lainnya. Dalam jangka waktu lama stres karena berbagai faktor bisa meningkatkan risiko kondisi kronis seperti diabetes, penyakit jantung, kolesterol tinggi dan hipertensi.

Dengan keterikatan antara kebisingan terhadap kesehatan para pekerja bidang industri, bidang arsitektur seharusnya dapat membantu dengan menghadirkan suatu bangunan yang berfungsi sebagai peningkatan kesehatan (promotif), pencegahan penyakit (preventif), penyembuhan penyakit (kuratif), dan pemulihan kesehatan (rehabilitatif). Karena kesehatan kerja bertujuan untuk memberi bantuan kepada tenaga kerja, melindungi tenaga kerja dari gangguan kesehatan yang timbul dari pekerjaan dan lingkungan kerja, meningkatkan kesehatan, memberi pengobatan dan perawatan serta rehabilitas. (PerMenNaKer no.13 tahun 2011). Kesehatan dan Keselamatan Kerja di artikan sebagai pemikiran dan upaya untuk menjamin keutuhan dan kesempurnaan baik jasmani maupun rohani tenaga kerja pada khususnya manusia (Armanda, 2006). 


\section{Rumusan Permasalahan}

- Bagaimana suatu program arsitektur dapat meminimalisir permasalahan kesehatan mental, terutama bagi para pekerja industri yang secara langsung terpapar oleh polusi suara (kebisingan) dalam waktu yang lama.

- Bagaimana suatu desain arsitektur dapat melampaui ekologi mengambil peran untuk mencegah dan menyembuhkan permasalahan kesehatan mental akibat stress yang ditimbulkan akibat bekerja di lingkungan yang bising dan meningkatkan kualitas hidup manusia.

\section{Tujuan}

- Proyek dapat menunjukkan kualitas bangunan sebagaimana fungsi yang telah ditentukan, dengan memerhatikan kualitas hidup para pekerja di kawasan industri Jababeka.

- Menjadikan proyek sebagai acuan suatu program dan desain yang dibutuhkan untuk para pekerja industri, sehingga kesehatan mental dapat dijaga, dan dapat meningkatkan kualitas hidup.

\section{KAJIAN LITERATUR}

\section{Kebisingan}

Sumber kebisingan di perusahaan biasanya berasal dari mesin-mesin untuk proses produksi dan alat-alat lain yang dipakai untuk melakukan pekerjaan. Sumber-sumber tersebut harus diidentifikasi dan dinilai kehadirannya agar dapat dipantau sedini mungkin dalam upaya mencegah dan mengendalikan pengaruh paparan kebisingan terhadap pekerja yang terpapar. Lingkungan kerja industri, memiliki tingkat kebisingan yang relatif tinggi sehingga harus ada batas waktu pajanan kebisingan. The Workplace and Safety (Noise) Compliance Standar 1995, SL No 381 menetapkan batasan kebisingan yang diberikan adalah 8 jam terus menerus pada level tekanan suara $85 \mathrm{~dB}(\mathrm{~A})$, dengan refrensi 20 micropascal.

Tabel 1. Nilai ambang batas kebisingan

\begin{tabular}{lcc}
\hline No & Waktu Pemajanan Per Hari & \multicolumn{2}{c}{ Tingkat Suara Dalam dB (A) } \\
\hline 1 & 8 jam & 85 \\
2 & 4 jam & 88 \\
3 & 2 jam & 91 \\
4 & 1 jam & 94 \\
5 & 30 menit & 97 \\
6 & 15 menit & 100 \\
7 & 7,5 menit & 130 \\
8 & 3,5 menit & 106 \\
9 & 1,88 menit & 109 \\
\hline
\end{tabular}

Sumber: The Workplace and Safety (Noise) Compliance Standar 1995, SL No 381

Berdasarkan tinggi rendahnya intensitas kebisingan dan lamanya waktu pemaparan, pengaruh pemaparan dibagi menjadi dua kategori yaitu Pengaruh pemaparan kebisingan intensias tinggi atau diatas Nilai Ambang Batas (NAB) dan pengaruh pemaparan kebisingan intensitas rendah (di bawah NAB).

Intensitas kebisingan yang tinggi atau diatas nilai ambang batas banyak dijumpai pada lingkungan yang berisik seperti, pabrik, bandara, tempat konser, dan lain-lain. Dapat memberikan dampak seperti merusak indera pendengaran sehingga daya dengar mengalami penurunan yang sifatnya sementara maupun bersifat permanen atau ketulian. Pengaruh kebisingan akan sangat terasa apabila jenis kebisingan merupakan kebisingan terputus - putus 
dan sumber yang tidak diketahui. Secara fisiologis, juga mempengaruhi kesehatan jangka panjang meliputi meningkatnya tekanan darah dan tekanan jantung, resiko serangan jantung meningkat, dan gangguan pencernaan.

Tingkat kebisingan dengan intensitas rendah banyak ditemukan di lingkungan kerja seperti kantor, sekolah, ruang administrasi, dan lain - lain. Kebisingan dibawah NAB secara fisiologis masih aman dan tidak membahayakan kualitas pendengaran. Namun kehadirannya turut memberikan dampak pada tingkat stres, menyebabkan penurunan performansi kerja dan gangguan kesehatan lainnya. Stres yang disebabkan karena pemaparan kebisingan dapat menyebabkan terjadinya kelelahan dini, kegelisahan dan depresi. Secara spesifik stres karena kebisingan tersebut dapat menyebabkan antara lain:

a. Stres menuju keadaan cepat marah, sakit kepala, dan gangguan tidur.

b. Gangguan reaksi psikomotor

c. Kehilangan konsentrasi

d. Penurunan performansi kerja yang dapat menimbulkan kehilangan efisiensi dan produktivitas kerja.

Berdasarkan penelitian NASA 1989 efek dari kebisingan dapat mempengaruhi kinerja pekerjaan seseorang adalah:

1. Bila intensitas kebisingan terus meningkat, maka peningkatan yang ditimbulkan tersebut dapat mempengaruhi kinerja. Apabila suatu intensitas melebihi batas tertentu maka akan menurunkan kinerja.

2. Kebisingan yang datang tiba-tiba dan tidak diharapkan dapat menyebabkan sebuah respon mengejutkan yang mengganggu konsentrasi dan kinerja kerja fisik.

3. Kebisingan yang terjadi secara periodik dengan frekuensi yang berulang akan dapat mengurangi konsentrasi dalam pekerjaan rumit.

Efek psikologis antara lain kegelisahan, keadaan tak berdaya dan pengaruh lain yang merugikan kinerja. Didasari pula bahwa pada lingkungan yang berisik, berfikir akan menjadi sulit. Percobaan laboratorium juga dapat membuktikan bahwa lingkungan berisik mengurangi kemampuan menghitung, mengetik, dan berkonsentrasi. Percobaan lain diketahui bahwa bising akan memperlambat waktu reaksi dan dapat menghadang daya reaksi.

\section{Kesehatan Mental}

Menurut Pieper dan Uden (2006), kesehatan mental adalah suatu keadaan dimana seseorang tidak mengalami perasaan bersalah terhadap dirinya sendiri, memiliki estimasi yang relistis terhadap dirinya sendiri dan dapat menerima kekurangan atau kelemahannya, kemampuan menghadapi masalah-masalah dalam hidupnya, memiliki kepuasan dalam kehidupan sosialnya, serta memiliki kebahagiaan dalam hidupnya. Jika kesehatan mental terganggu, maka timbul gangguan mental atau penyakit mental. Gangguan mental dapat mengubah cara seseorang dalam menangani stres, berhubungan dengan orang lain, membuat pilihan, dan memicu hasrat untuk menyakiti diri sendiri.

Beberapa jenis gangguan mental yang umum ditemukan, antara lain depresi, gangguan bipolar, kecemasan, gangguan stres pasca trauma (PTSD), gangguan obsesif kompulsif, dan psikosis. Prinsip-prinsip dalam pengertian kesehatan mental meliputi :

a. Kesehatan mental merupakan lebih dari tidak ada nya perilaku abnormal. Prinsip ini menegaskan bahwa yang tergolong sehat mentalnya tidak cukup bila dikatakan sebagai orang yang tidak megalami abnormalitas atau orang yang normal. Karena pendekatan statistik memberikan kelemahan pemahaman normalitas itu. Konsep kesehatan mental lebih memiliki makna positif dibanding makna keadaan umum atau normalitas sebagaimana konsep statistik. 
b. Kesehatan mental adalah konsep yang ideal. Prinsip ini menegaskan bahwa kesehatan mental menjadi prioritas bagi seseorang. Apalagi disadari bahwa kesehatan mental itu bersifat kontinum. Sehingga sedapat mungkin orang mendapatkan kondisi sehat yang paling optimal dan berusaha terus untuk mencapai kondisi sehat tertinggi.

c. Kesehatan mental sebagai bagian dan karakteristik kualitas hidup. Prinsip ini menegaskan bahwa kualitas hidup seseorang tercerminkan dari Kesehatan mentalnya. Tidak mungkin membiarkan kesehatan mental seseorang untuk mencapai kualitas hidupnya, atau sebaliknya kualitas hidup seseorang dapat dikatakan meningkat jika juga terjadi peningkatan dari kesehatan mentalnya.

Kesehatan mental di lingkungan kerja selayaknya dijaga, dengan memperhatikan kesehatan mental dan keselamatan para pekerja akan mempengaruhi produktivitas pekerja terhadap perusahaan. Terganggunya kesehatan mental dapat mempengaruhi performa kerja dan produktivitas, hubungan antar rekan kerja, kemampuan fisik, dan sehari-hari seseorang baik di tempat kerja maupun di rumah. Menurut Charles Goldstein, seorang professor psikiater klinis dari New York University Langone School of Medicine, menyatakan bahwa otak manusia berpengaruh terhadap kesehatan mental karena memiliki hubungan erat dengan sistem endokrin yang melepaskan hormon penting. Sehingga dapat disimpulkan bahwa ketika gangguan mental didapati berarti secara biologis, terdapat gangguan sistem kerja otak manusia. Terganggunya cara kerja otak tersebut, berdasarkan fakta yang dipublikasi Organisasi Kesehatan Dunia (WHO), telah menimbulkan kerugian ekonomi yang cukup signifikan. Diperkirakan kerugian ekonomi secara global adalah satu triliun dollar, dikarenakan berkurangnya produktivitas akibat permasalahan kesehatan mental.

\section{METODE}

\section{Pendekatan Desain}

Desain Biofilik adalah pendekatan arsitektur yang berupaya menghubungkan penghuni bangunan lebih dekat dengan alam. Bangunan yang dirancang biofilik menggabungkan hal-hal seperti pencahayaan dan ventilasi alami, kontur lanskap alam, dan elemen lain untuk menciptakan lingkungan binaan yang lebih produktif dan sehat bagi manusia. Biofilia adalah kecenderungan manusia yang melekat untuk bersosialisasi dengan alam yang bahkan di dunia modern terus menjadi penting bagi kesehatan, kesejahteraan fisik dan mental manusia (Kellert $1997,2012)$

Desain biofilik dapat mengurangi stres, meningkatkan fungsi kognitif dan kreativitas, meningkatkan kesejahteraan kita dan mempercepat penyembuhan; karena populasi dunia terus melakukan urbanisasi menjadikan hal-hal ini semakin penting. Mengingat seberapa cepat sebuah pengalaman alam dapat menimbulkan respons restoratif, dan fakta bahwa bisnis menyia-nyiakan miliaran dolar setiap tahun karena kehilangan produktivitas akibat stres dan penyakit, desain yang menghubungkan kembali kita dengan alam - desain biofilik - sangat penting untuk memberikan kesempatan kepada orang-orang untuk tinggal dan bekerja di tempat dan ruang yang sehat dengan lebih sedikit stres dan kesehatan dan kesejahteraan yang lebih besar secara keseluruhan. 


\section{Pola dari Desain Biofilik}

Tabel 2. 14 Pola desain Biofilik.

\begin{tabular}{|c|c|c|c|c|c|}
\hline \multicolumn{2}{|c|}{14 PATTERNS } & \multirow{2}{*}{\begin{tabular}{l|}
$*$ \\
\\
\end{tabular}} & \multirow{2}{*}{$\begin{array}{l}\text { STRESS REDUCTION } \\
\text { Lowered blood pressure and heart rate } \\
\text { (Brown, Barton \& Gladwell, 2013; van den Berg, } \\
\text { Hartig, \& Staats, 2007; Tsunetsugu \& Miyazzk, 2005) } \\
\end{array}$} & \multirow{2}{*}{$\begin{array}{l}\text { COGNITIVE PERFORMANCE } \\
\text { Improved mental engagement/ } \\
\text { attentiveness } \\
\text { (Biederman \& Vessel, 2006) }\end{array}$} & \multirow{2}{*}{\begin{tabular}{|l} 
EMOTION, MOOD \& PREFERENCE \\
$\begin{array}{l}\text { Positively impacted attitude } \\
\text { and overall happiness } \\
\text { (Barton \& Pretty, 2010) }\end{array}$ \\
\end{tabular}} \\
\hline \multirow{7}{*}{ 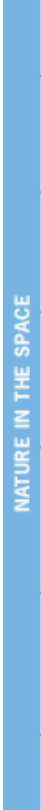 } & $\begin{array}{l}\text { Visual } \\
\text { Connection } \\
\text { with Nature }\end{array}$ & & & & \\
\hline & $\begin{array}{l}\text { Non-Visual } \\
\text { Connection } \\
\text { with Nature }\end{array}$ & $\dot{*}$ & $\begin{array}{l}\text { Reduced systolic blood pressure } \\
\text { and stress hormones } \\
\text { (Park, Tsunetsugu, Kasetani et al., 2009; Hartig, } \\
\text { Evans, Jarmer et al., 2003; Orsega-Smith, Mowen, } \\
\text { Payne et al., 2004; Ulich, Simons, Losito et al., 1991) }\end{array}$ & $\begin{array}{l}\text { Positively impacted on } \\
\text { cognitive performance } \\
\text { (Mehta, Zhu \& Cheema, 2012; Ljungberg, } \\
\text { Neely, \& Lundstrơm, 2004) }\end{array}$ & $\begin{array}{l}\text { Perceived improvements in } \\
\text { mental health and tranquility } \\
\text { (Li, Kobayashi, Inagaki et al., 2012; Jahncke, et al., } \\
2011 \text {; Tsunetsugu, Park, \& Myazaki, 2010; Kim, } \\
\text { Ren, \& Fielding, 2007; Stigsdotter \& Grahn, 2003) }\end{array}$ \\
\hline & $\begin{array}{l}\text { Non-Rhythmic } \\
\text { Sensory Stimuli }\end{array}$ & : & $\begin{array}{l}\text { Positively impacted on heart } \\
\text { rate, systolic blood pressure and } \\
\text { sympathetic nervous system activity } \\
\text { (Li, 2009; Park et al, 2008; Kahn et al., 2008; } \\
\text { Beauchamp, et al., 2003; Urich et al., 1991) }\end{array}$ & $\begin{array}{l}\text { Observed and quantified behavioral } \\
\text { measures of attention and } \\
\text { exploration (Windhager et al., 2011) }\end{array}$ & \\
\hline & $\begin{array}{l}\text { Thermal } \\
\text { \& Airflow } \\
\text { Variability }\end{array}$ & $\dot{*}$ & $\begin{array}{l}\text { Positively impacted comfort, } \\
\text { well-being and productivity, } \\
\text { (Heerwagen, 2006; Tham \& Wlem, 2005; WGō, 2005) }\end{array}$ & $\begin{array}{l}\text { Positively impacted concentration } \\
\text { (Hartig et al, 2003; Hartig et al., } \\
\text { 1991; R. Kaplan \& Kaplan, 1989) }\end{array}$ & $\begin{array}{l}\text { Improved perception of temporal } \\
\text { and spatial pleasure (alliesthesia) } \\
\text { (Parkinson, de Dear \& Candido, 2012; Zhang, } \\
\text { Arens, Huizenga \& Han, 2010; Arens, Zhang. } \\
\text { \& Huizenga, 2006; Zlang, 2003; de Dear } \\
\text { \& Brager, 2002; Heschong, 1979) }\end{array}$ \\
\hline & $\begin{array}{l}\text { Presence } \\
\text { of Water }\end{array}$ & $:$ & $\begin{array}{l}\text { Reduced stress, increased } \\
\text { feelings of tranquility, lower heart } \\
\text { rate and blood pressure } \\
\text { (Avarsson, Wiers, \& Nilsson, 2010; Pheasart, Fisher, } \\
\text { Watts et al., 2010; Biederman \& Vessel, 2006) }\end{array}$ & $\begin{array}{l}\text { Improved concentration and } \\
\text { memory restoration } \\
\text { (Alvarsson et al., 2010; Biederman \& Vessel, 2006) } \\
\text { Enhanced perception and } \\
\text { psychological responsiveness } \\
\text { (Alvarsson et al., 2010; Hunter et al., 2010) }\end{array}$ & $\begin{array}{l}\text { Observed preferences and } \\
\text { positive emotional responses } \\
\text { (Windhager, 2011; Bartton \& Pretty, 2010; White, } \\
\text { Smith, Humphryes et al., 2010; Karmanov \& Hamel, } \\
\text { 2008; Biederman \& Vessel, 2006; Heerwagen \& } \\
\text { Orians, 1993; Ruso \& Atzwanger, 2003; Ulrich, 1983) }\end{array}$ \\
\hline & $\begin{array}{l}\text { Dynamic \& } \\
\text { Diffuse Light }\end{array}$ & $\dot{*}$ & $\begin{array}{l}\text { Positively impacted circadian } \\
\text { system functioning } \\
\text { (Figueiro, Brons, Pitricket al., 2011; } \\
\text { Beckett \& Roden, 2009) } \\
\text { Increased visual comfort } \\
\text { (Elyezad, 2012; Kim \& Kim, 2007) }\end{array}$ & & \\
\hline & $\begin{array}{l}\text { Connection with } \\
\text { Natural Systems }\end{array}$ & & & & $\begin{array}{l}\text { Enhanced positive health responses; } \\
\text { Shifted perception of environment } \\
\text { (Kellert et al., 2008) }\end{array}$ \\
\hline \multirow{3}{*}{ 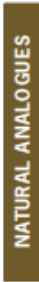 } & $\begin{array}{l}\text { Biomorphic } \\
\text { Forms \& } \\
\text { Patterns }\end{array}$ & $\cdot$ & & & $\begin{array}{l}\text { Observed view preference } \\
\text { (Vessel, 2012; Joye, 2007) }\end{array}$ \\
\hline & $\begin{array}{l}\text { Material } \\
\text { Connection } \\
\text { with Nature }\end{array}$ & & & $\begin{array}{l}\text { Decreased diastolic blood pressure } \\
\text { (Tsunetsugu, Miyazaki \& Sato, 2007) } \\
\text { Improved creative performance } \\
\text { (Lichtenfeld et al., 2012) }\end{array}$ & $\begin{array}{l}\text { Improved comfort } \\
\text { (Tsunetsugu, Miyazaki \& Sato 2007) }\end{array}$ \\
\hline & $\begin{array}{l}\text { Complexity } \\
\text { \& Order }\end{array}$ & $:$ & $\begin{array}{l}\text { Positively impacted perceptual and } \\
\text { physiological stress responses } \\
\text { (Salingaros, 2012; Joye, 2007; } \\
\text { Taylor, 2006; S. Kaplan, 1988) }\end{array}$ & & $\begin{array}{l}\text { Observed view preference } \\
\text { (Salingaros, 2012; Hägerhall, Laike, } \\
\text { Taylor et al, 2008; Hägerhall, Purcella, } \\
\text { \& Taylor, 2004; Taylor, 2006) }\end{array}$ \\
\hline \multirow{4}{*}{ 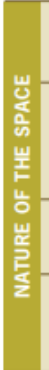 } & Prospect & $:$ & $\begin{array}{l}\text { Reduced stress } \\
\text { (Grahn \& Stigsdotter, 2010) }\end{array}$ & $\begin{array}{l}\text { Reduced boredom, irritation, } \\
\text { fatigue (Clearwater \& Coss, 1991) }\end{array}$ & $\begin{array}{l}\text { Improved comfort and perceived } \\
\text { safety (Herzog \& Bryce, 2007; Wang } \\
\text { \& Taylor, 2006; Petherick, 2000) }\end{array}$ \\
\hline & Refuge & $\dot{\bullet}$ & & $\begin{array}{l}\text { Improved concentration, attention } \\
\text { and perception of safety } \\
\text { (Grahn \& Stigsdotter, 2010; Wang \& } \\
\text { Taylor, 2006; Wang \& Taylor, 2006; } \\
\text { Petherick, 2000; Ulrich et al., 1993) }\end{array}$ & \\
\hline & Mystery & $:$ & & & $\begin{array}{l}\text { Induced strong pleasure response } \\
\text { (Biederman, 2011; Salimpoor, Benovoy, Larcher et } \\
\text { al, 2011; |kemi, 2005; Blood \& Zatorre, 2001) }\end{array}$ \\
\hline & Risk/Peril & $\cdot$ & & & $\begin{array}{l}\text { Resulted in strong dopamine } \\
\text { or pleasure responses } \\
\text { (Kohno et al., 2013; Wang \& Tsien, } \\
\text { 2011; Zald et al., 2008) }\end{array}$ \\
\hline
\end{tabular}

C 2014 Terrapin Bright Green / 14 Patterns of Biophilic Design

Sumber: 14 Patterns of Biophilic Design

Dalam buku 14 Patterns of Biophilic Design karya Terrapin Bright Green terdapat aspek - aspek yang perlu diperhatika di dalam desain biofilik, peran - peran tersebut meliputi:

A. Alam dalam suatu area

membahas kehadiran langsung, fisik, dan fana dari alam dalam suatu ruang atau tempat. Ini termasuk kehidupan tumbuhan, air dan hewan, juga seperti angin sepoi-sepoi, suara, aroma dan elemen alam lainnya.

B. Analogi Alami

membahas pembangkitan organik, tidak hidup, dan tidak langsung dari alam. Benda, bahan, warna, bentuk, urutan, dan pola yang ditemukan di alam, bermanifestasi sebagai karya seni, ornamen, furnitur, dekorasi, dan tekstil di lingkungan binaan.

C. Alam dari suatu area

membahas konfigurasi spasial di alam. Ini termasuk kami keinginan bawaan dan terpelajar untuk dapat melihat melampaui lingkungan terdekat kita, ketertarikan kita dengan hal-hal yang sedikit 
berbahaya atau tidak diketahui; pandangan kabur dan saat-saat pewahyuan; dan kadangkadang bahkan sifat yang memicu fobia ketika mereka termasuk elemen keamanan yang tepercaya.

\section{DISKUSI DAN HASIL}

\section{Tapak}

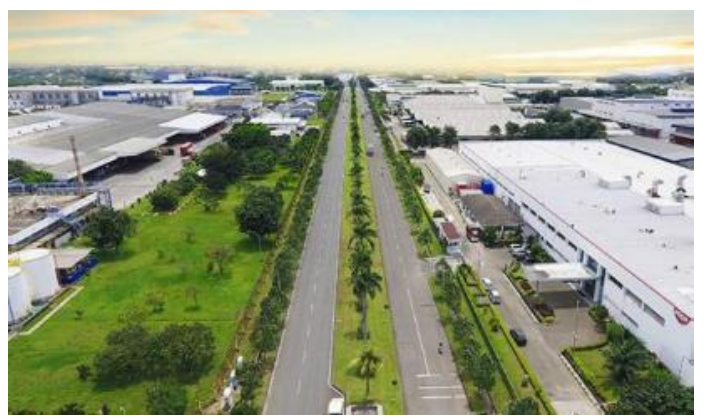

Gambar 1. Area Jababeka

Sumber: Sindonews.com

Kawasan industri Bekasi atau yang akrab disebut kawasan Jababeka Cikarang berdasarkan data yang didapat dari jababekaindustrial.com terdapat setidaknya 2000 perusahaan yang ada didalamnya dibidang produksi, menampun kurang lebih 730000 tenaga kerja, menjadikan kawasan ini sebagai salah satu pusat industri di Indonesia.

Berdasarakan data yang ada tercatat luas area jababeka mencapai 5600 Ha dengan populasi sebesar 1.200.000 jiwa selain industri terdapat fungsi residential, pendidikan, rekreasi di dalamnya.

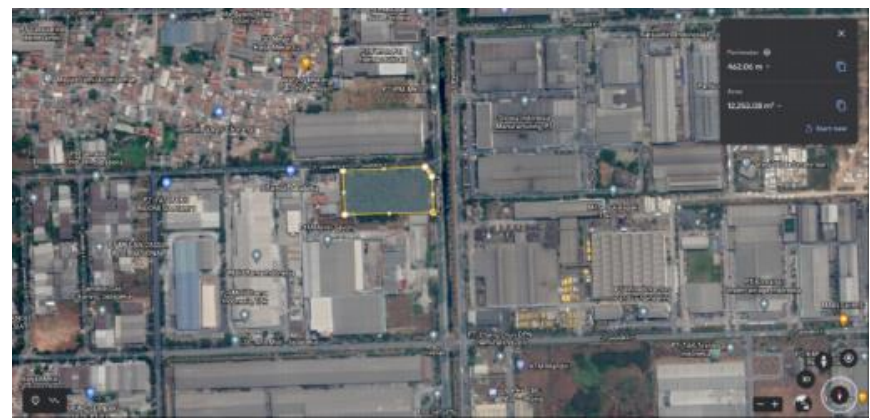

Gambar 2. Peta Lokasi Tapak.

Sumber: earth.google.com

Lokasi : Harja Mekar, Kec. Cikarang Utara, Bekasi, Jawa Barat

Luas $\quad: \pm 14276 \mathrm{~m} 2$
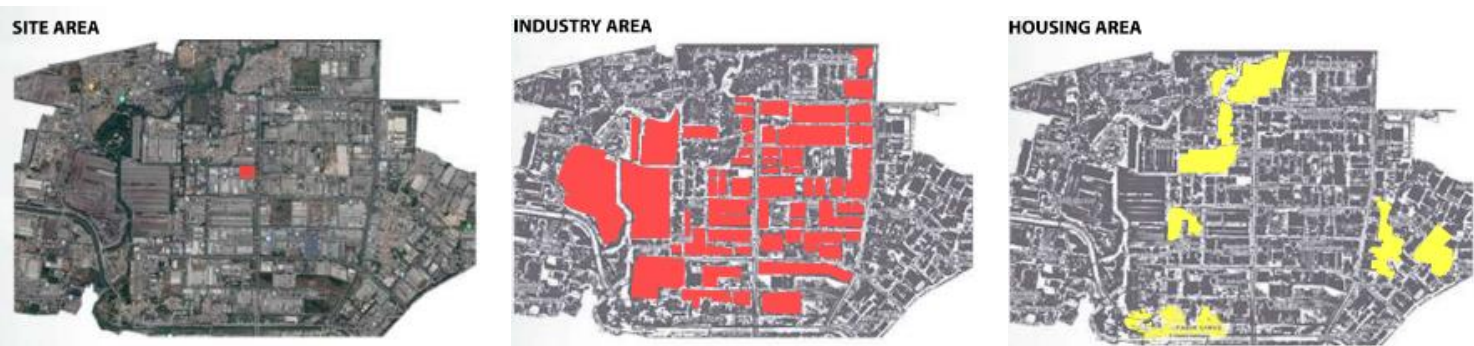

Gambar 3. Diagram Pemetaan Fungsi Bangunan

Sumber: earth.google.com 
Pada kawasan sekitar tapak didominasi oleh bangunan dengan fungsi industri (merah) pada gambar 15. Industri yang ada pada sekitar terdiri dari berbagai sector seperti produksi barang konsumsi (Unilever), tekstil maupun peralatan berat (United Tractors). Selain kawasan industri juga terdapat beberapa kawasan pemukiman, penghuni pada kawasan tersebut idealnya para penghuni juga merupakan para pekerja yang bekerja pada perusahaan perusahaan yang ada di Jababeka.

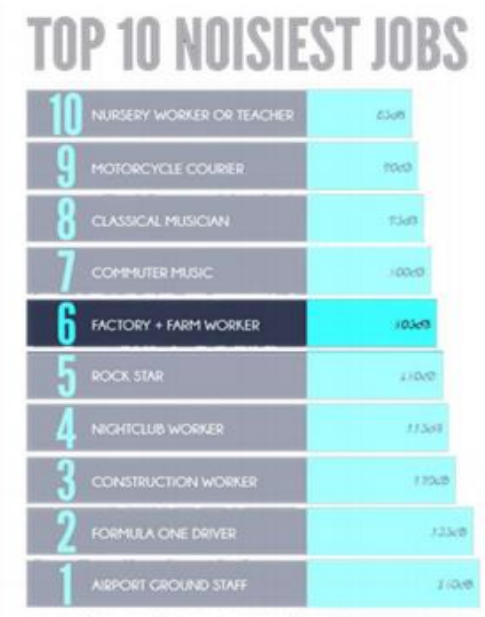

Gambar 4. 10 Pekerjaan Terbising

Sumber: acousticalsurfaces.com

Dilansir dari Acoustical Surfaces, para pekerja industri bersama dengan para pekerja di bidang pertanian berada di urutan ke enam dalam kategori pekerjaan dengan kebisingan tertinggi, mencapai $105 \mathrm{~dB}$. Tentunya area Jababeka dengan tenaga kerja yang mencapai ratusan ribu perlu diperhatikan kesejahteraan para pekerja nya. Karena kebisingan dapat membahayakan Kesehatan fisik dan psikis. Hal ini tentu dapat mengganggu produktifitas dalam bekerja dan kesehatan dalam jangka panjang.

\section{Hasil Pendekatan}

Usulan bangunan yang dihasilkan adalah pusat perawatan psikologis yang memenuhi kebutuhan pengguna dengan menghadirkan program yang berfungsi sebagai peningkatan kesehatan (promotif), pencegahan penyakit (preventif), penyembuhan penyakit (kuratif), dan pemulihan kesehatan (rehabilitatif).
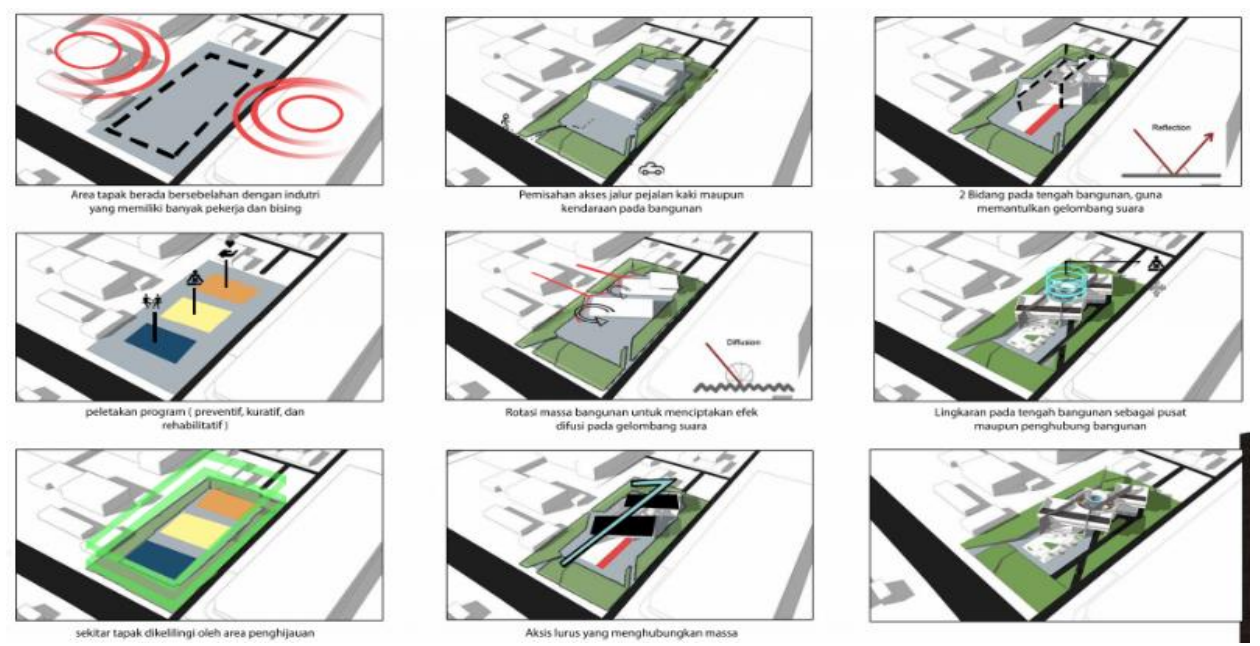

Gambar 5. Proses Gubahan

Sumber: Dokumentasi Pribadi, 2021 
Pembentukan massa bangunan didasari dengan beberapa aspek yang merupakan poin penting dari desain biofilik, poin - poin pembentukan massa meliputi:

a. Pembagian massa dibagi menjadi 3 zonasi yang meliputi ruang rehabilitatif, kuratif, dan preventif

b. Massa dirotasi 45 derajat dari axis tapak, mengambil karakteristik suara yang lebih terpencar bila mengenai suatu bidang yang memiliki kemiringan.

c. Area penghijauan atau buffer yang mengitari semua bangunan.

d. Aspek biofilik yang diterapkan kepada setiap ruangan yang ada sehingga setiap ruangan mendapatkan karakteristik suatu ruang yang memiliki elemen alam didalamnya.

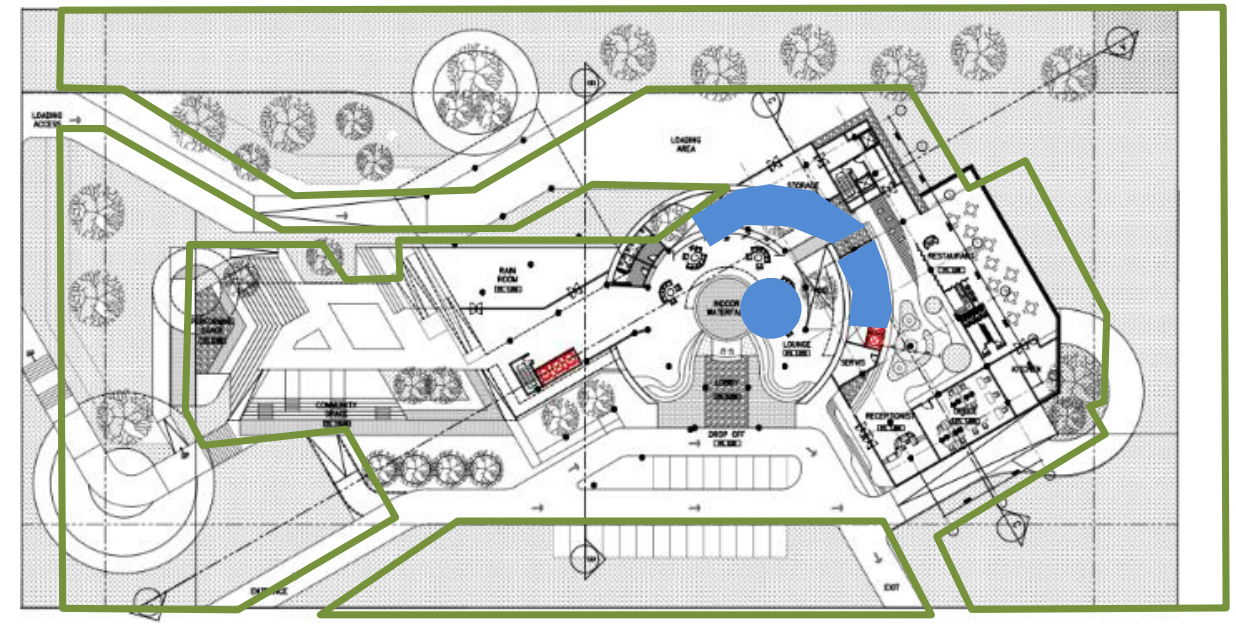

Gambar 6. Denah lantai 1

Sumber: Dokumentasi Pribadi, 2021

Terlihat dari pengaplikasian pada denah lantai satu, bahwa area hijau (hijau) pada bangunan menutupi dan mengitari seluruh massa bangunan, selain berfungsi sebagai area resapan juga berfungsi sebagai peneduh dan merupakan karakteristik desain biofilik yang mengedepankan area hijau pada suatu bangunan. Tidak hanya area hijau disekitar bangunan penghadiran karakteristik alam juga dimasukkan kedalam bangunan (biru) sehingga setiap ruang tidak ada yang liput dari karakteristik alam untuk memenuhi unsur biofilik.

Dengan seperti itu juga massa bangunan pada area tengah tidak ada yang sepenuh nya terpapar tanpa perlindungan area hijau, tidak ada bukaan - bukaan yang terlalu masif ataupun lebar langsung menghadap kearah bangunan.

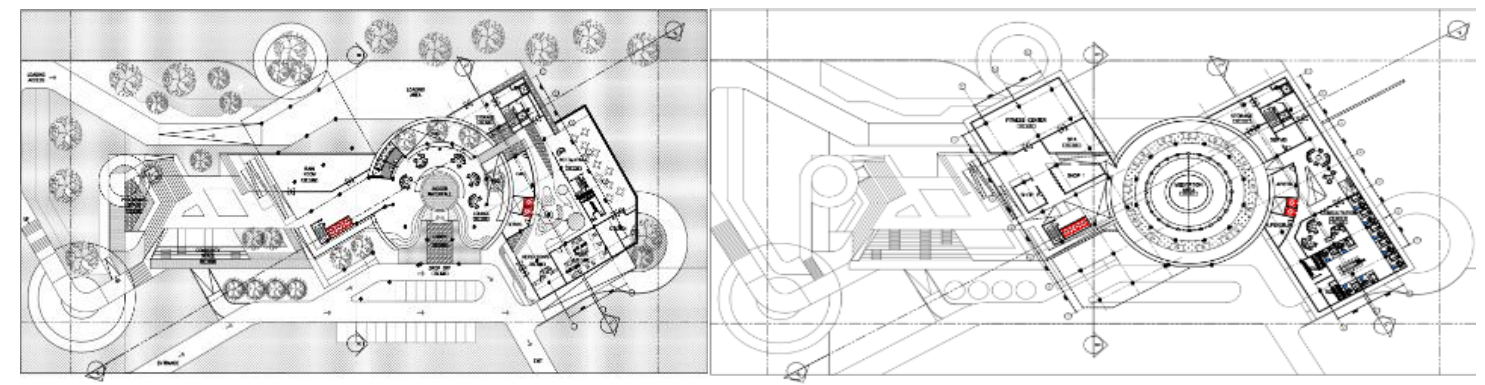

Gambar 7. Denah lantai 2 dan 3.

Sumber: Dokumentasi Pribadi, 2021

Ruang - ruang atas fasilitas pada bangunan juga dibuat sebagai sarana penenang atau pereda stres bagi pengguna bangunan, dengan tujuan para pekerja industri yang menggunakan 
bangunan ini dapat mengimbangi hidupnya yang sudah bekerja keras di industri, sehingga kesehatan baik fisik maupun mental dapat terjaga. Fasilitas - fasilitas yang ada pada bangunan meliputi:

1. Pusat Meditasi: merupakan sarana pencegahan penyakit (preventif) didalamnya terdapat berbagai ruang mulai dari ruang meditasi, aula meditasi, kantor pengurus, air terjun dalam ruang, ruang tunggu, lobby dan lainnya

2. Pusat Konsultasi: merupakan area penyembuhan (kuratif) bagi para pengguna bangunan yang memiliki kesehatan mental yang serius (depresi,dan lainnya) untuk melakukan penanganan lebih lanjut. Terdapat ruang konsultasi, ruang psikolog, ruang tunggu, resepsionis dan berbagai fasilitas pendukung lainnya.

3. Pusat Komunitas: merupakan area rehabilitatif yang didalamnya terdapat berbagai ruang interaksi antar sesama pekerja, seperti plaza, amphiteater, café, dan lainnya.

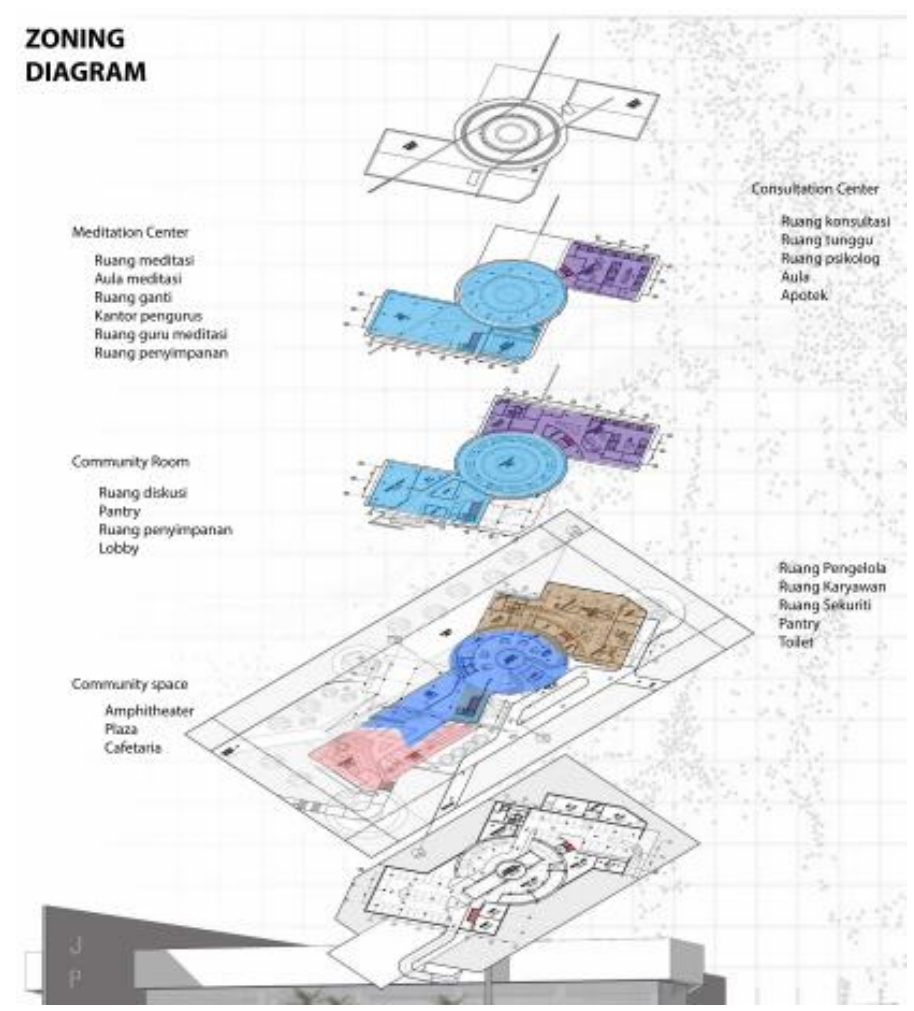

Gambar 8. Diagram Zonasi

Sumber: Dokumentasi Pribadi, 2021

Pembagian ruang pada bangunan dimulai dari zona rehabilitatif (merah muda), preventif (biru) dan kuratif (ungu). Itu adalah urutan dari healing sequence yang akan diciptakan berdasarkan tingkat parahnya suatu penyakit psikis. Area kuratif atau pusat konsultasi diletakkan paling belakang dengan tujuan ruang akan terasa lebih hening dan intim sehingga dikhususkan untuk pusat konsultasi. 


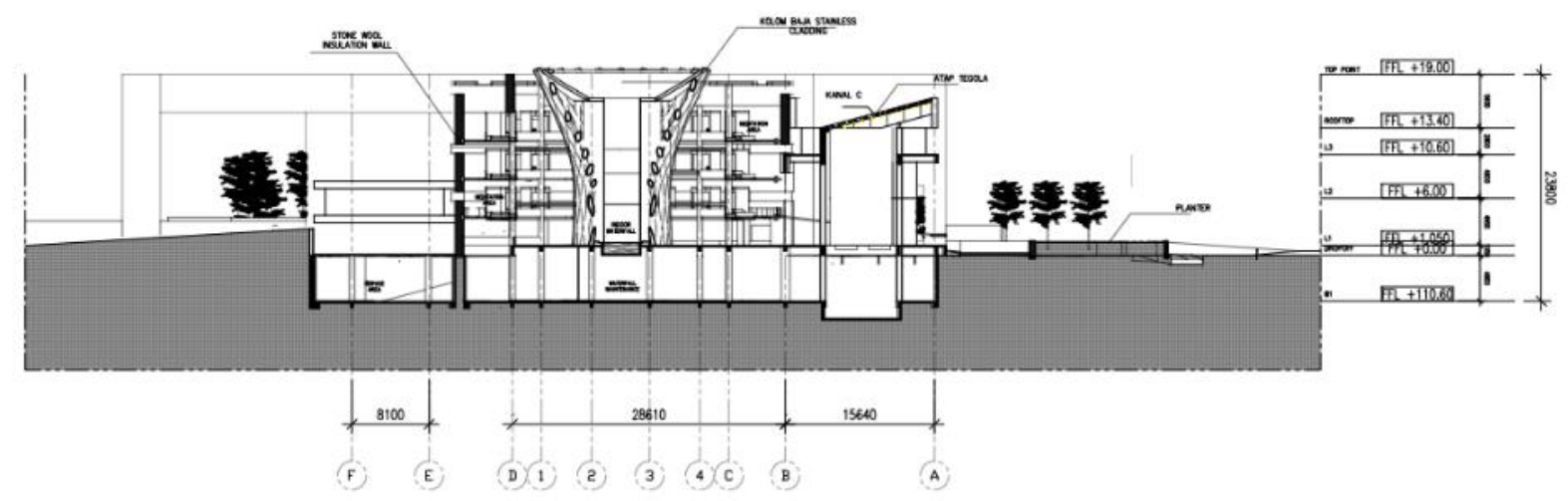

POT A - A

Gambar 9. Potongan Bangunan

Sumber: Dokumentasi Pribadi, 2021

Terlihat dari potongan area indoor waterfall sebagai pusat dari bangunan, digunakan sebagai sarana meditasi menghadirkan unsur alam yaitu air, sehingga meditasi dapat dilakukan dengan menghadap ke area tersebut.

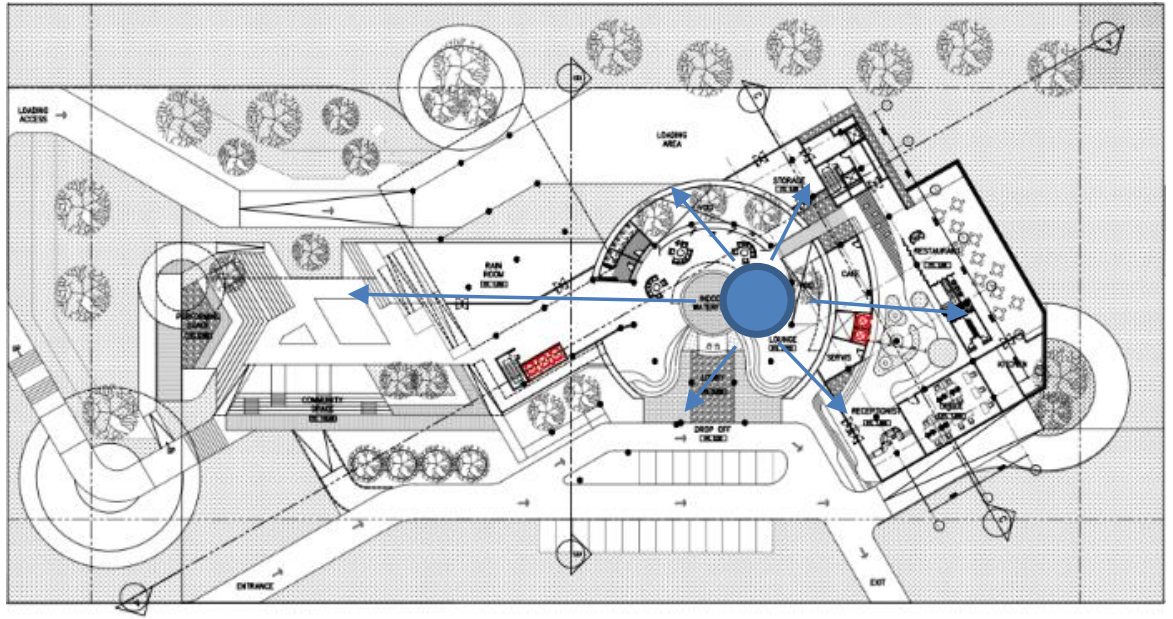

Gambar 10. Waterfall pada lantai 1

Sumber: Dokumentasi Pribadi, 2021

Unsur air dapat menghadirkan berbagai faktor alam lainnya yaitu mulai dari suara dan penghawaan (udara) diciptakan. faktor yang diakibatkan oleh unsur air tersebut tentunya membuat pengalaman ruang yang berbeda yang lebih mengarah kepada desain biofilik. sehingga meditasi dapat dilakukan dengan maksimal. Dan jangkauan dari suara air terjun juga luas sehingga banyak area pada bangunan mendapatkan pengalaman ruang yang khusus tercipta mulai dari suara, cahaya maupun udara. 


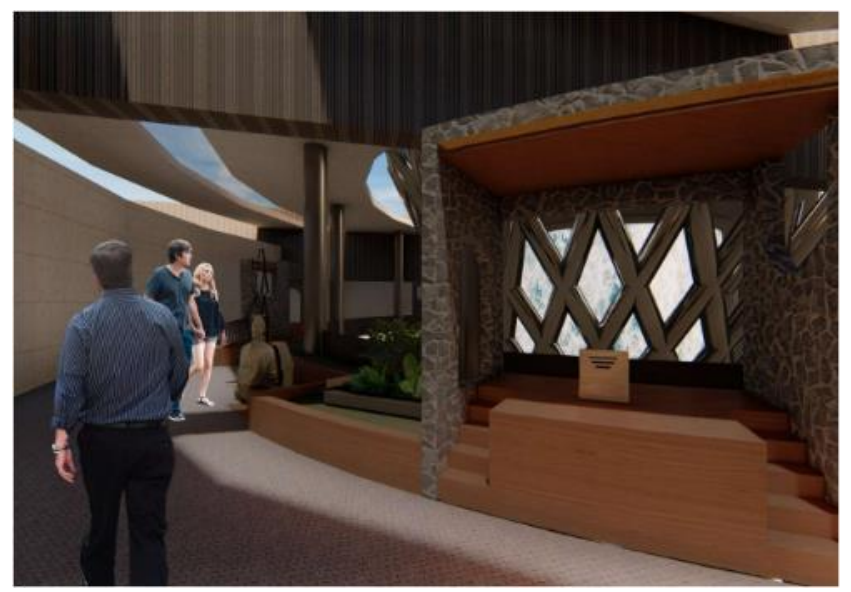

Gambar 11. Area Meditasi

Sumber: Dokumentasi Pribadi, 2021

Terlihat dari gambar, terdapat bilik - bilik khusus bagi pengguna yang ingin melangsungkan meditasi menghadap ke indoor waterfall bilik tersebut juga menghadirkan elemen alam seperti kayu dan batu, ruang belakan digunakan sebagai akses sirkulasi sehingga dibuat membelakangi, meditasi dipusatkan ke air terjun yang lebih dominan dari segi suara, penghawaan dan segi penglihatan. Cahaya pada atap bangunan (skylight) memberikan kesan keterbukaan pada alam diluar.

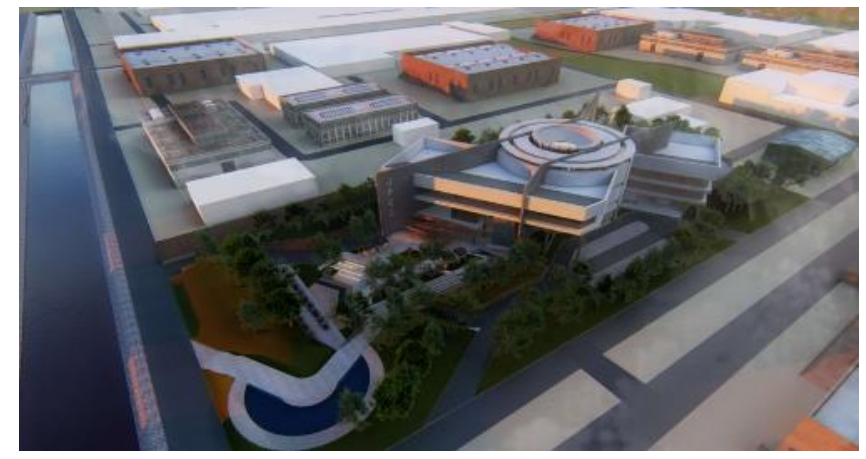

Gambar 12. Bird's-eye View Bangunan Sumber: Dokumentasi Pribadi, 2021

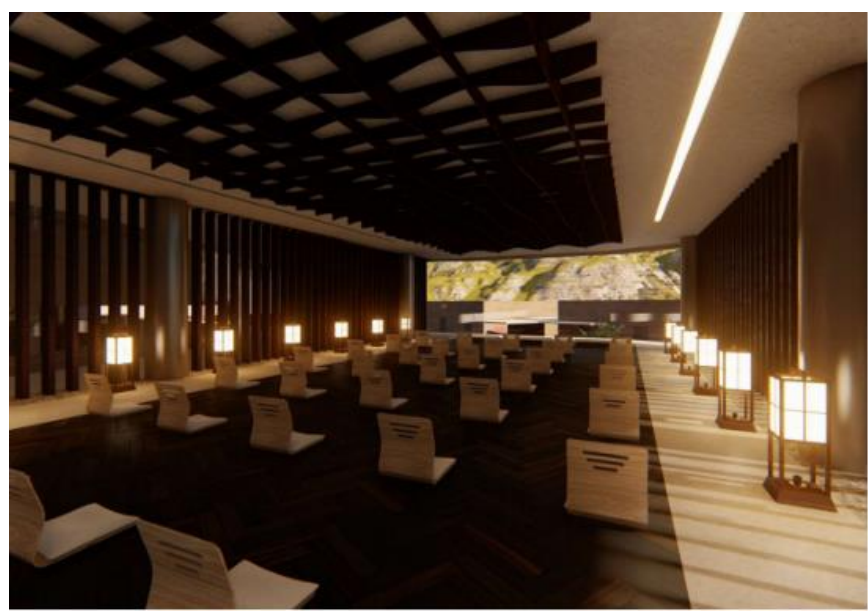

Gambar 13. Ruang Meditasi

Sumber: Dokumentasi Pribadi, 2021

Pada meditasi dalam ruangan dibuat tertutup, area yang menghadap ke pabrik dibuat perlakuan 
khusus seperti maretial kaca dua lapis sehingga dapat meredam suara bising pabrik. Unsur alam yang dominan dalah kayu, warna coklat yang menenangkan juga cahaya yang menghangatkan dibuat menjadi satu kesatuan didalam ruang.

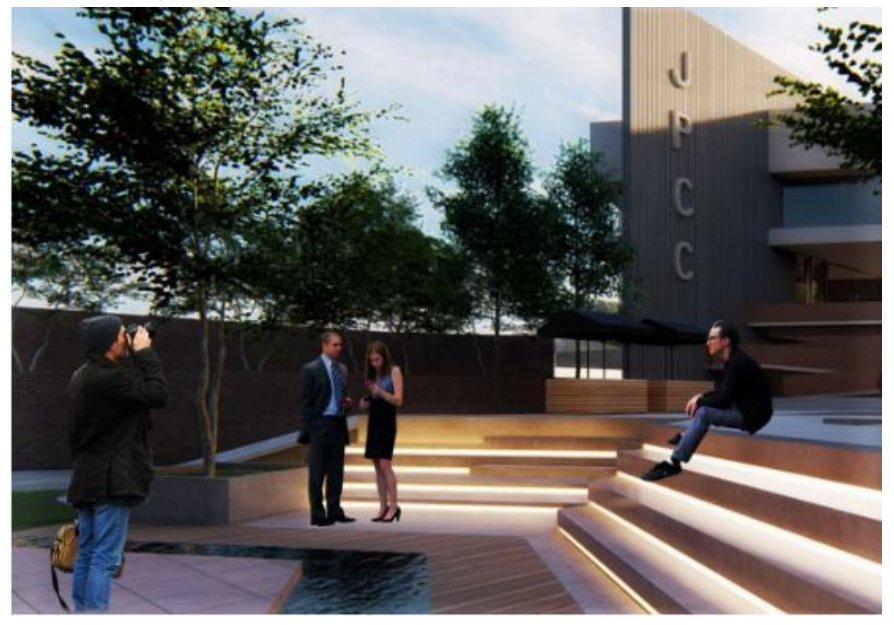

Gambar 14. Amphitheater Area

Sumber: Dokumentasi Pribadi, 2021

Area amphitheater sebagai sarana rehabilitatif untuk tempat berkumpul sebagai suatu komunitas dapat membantu penyembuhan didasari dengan dukungan komunitas yang kuat, dengan dikelilingi oleh area hijau dan banyak unsur alam (cahaya, udara, ruang terbuka) di dalamnya membuat suasana yang tercipta berbeda dari lingkungan kerja, sehingga para pengguna tidak merasakan stress seperti pada lingkungan kerja.

Juga tidak hanya digunakan untuk area kumpul, area ini dimanfaatkan sebagai area untuk berbagai warga sekitar menjual makanan maupun minuman. Sehingga muka bangunan terlihat begitu menyambut dengan berbagai aspek tersebut bangunan menjadi terbuka dengan tujuan pengguna bangunan maupun yang lewat disekitar tidak sungkan untuk masuk dan memnikmati fasilitas yang ada.

\section{KESIMPULAN DAN SARAN}

\section{Kesimpulan}

Percepatan teknologi yang terus maju tidak hanya memberikan dampak positif namun juga negatif. Kegiatan bekerja manual di berbagai tempat kerja berdampingan dengan mesin industri yang masih banyak dilakukan hal tersebut tidak hanya membantu para pekerja namun juga terdapat suatu hal yang dikorbankan, yaitu kesehatan mereka. Pekerja industri sebagai makhluk hidup tentunya ingin hidup dengan sejahtera, Pekerjaan yang terus dilakukan setiap harinya, di lingkungan yang bising dan padat tentunya menekan kesehatan fisik dan psikis mereka. Dengan ini, seharusnya arsitektur dapat bergerak dalam mengedepankan kesehatan mereka, baik dalam penyediaan fasilitas dengan desain yang dapat memberikan ketenangan, maupun penanganan keselamatan kerja di area industri. Sehingga mereka dapat terus bekerja namun dengan tetap dapat mengimbagi kesejahteraan mereka.

\section{Saran}

Desain biofilik dapat memberikan penanganan stress yang signifikan. Sektor industri mulai dapat memberikan contoh dan kontribusi dalam memerhatikan kesejahteraan pekerja nya. Dengan membangun fasilitas kesehatan psikis (yoga, meditasi, maupun rekreasi) menggunakan desain biofilik, Dengan demikian seorang pekerja dapat terus produktif dan maksimal dalam bekerja dan kesehatan psikis mereka tetap terpenuhi. 


\section{REFERENSI}

Armanda, D. (2006). Penerapan SMK3 Bidang Konstruksi Medan.

Babba, J. (2007). Hubungan Antara Intesitas Kebisingan di Lingkungan Kerja Dengan Peningkatan Tekanan Darah.

Green, T. B. (2014). 14 Patterns of Biophilic Design.

Jatnika, R. Q., Fachrul, M. F., \& Sintorini, M. M. (2018). Analisis Dampak Kebisingan Terhadap Kesehatan dan Keselamatan Kerja Karyawan Pada Industri Pemintalan Benang.

Kellert, S. R., Heerwagen, J., \& Mador, M. (2013). Biophilic Design: The Theory, Science and Practice of Bringing Buildings to Life.

Kemenakertrans RI. (2011). Permenakertrans No. 13/MEN/X/2011 Tentang Nilai Ambang Batas Faktor Fisika dan Faktor Kimia di Tempat Kerja. Jakarta.

Kementerian Keuangan RI. (2020, Desember 07). Kesehatan Mental di Lingkungan Kerja. Retrieved from https://www.djkn.kemenkeu.go.id/artikel/baca/13552/KesehatanMental-di-Lingkungan-Kerja.html

Koagouw, I. A., Supit, W., \& Rumampuk, J. F. (2013). Pengaruh Kebisingan Mesin Las Disel Listrik terhadap Fungsi Pendengaran pada Pekerja Bengkel Las Kecamatan Mapanget Kota Manado. 379-386.

Kurniawan, T. P., Wahyuningsih, N. E., \& Suhartono. (2012). Studi Kejadian Gangguan Pendengaran pada Masinis UPT Crew Kereta Api Solo Balapan. 130-138.

Lubis, T. U. (2020). Pengaruh Kesejahteraan Psikologis, Kompensasi dan Lingkungan Kerja Fisik Terhadap Kepuasan Kerja Karyawan Pada PT. Gracia Multi Moda Medan.

Nugroho, D. W. (2009). Pengaruh Intensitas Kebisingan Terhadap Kelelahan Kerja Pada Tenaga Kerja di PT. ANTAM Tbk. UBPE Pongkor, Bogor, Jawa Barat.

Pieper, J., \& Uden, M. v. (2006). Religion and Coping in Mental Health Care.

Rizkiani, L. A., \& Wardono, P. (2014). Perancangan Fasilitas Rehabilitasi Mental untuk Penderita Depresi.

Suma'mur, P. (1996). Higene Perusahaan Dan Kesehatan Kerja. Jakarta: Sagung Seto.

Taufik, M. I. (2019). Kajian Tingkat Kebisingan Terhadap Pekerja di Industri.

Tirupati, S. (2019). The Principles and Practice of Psychiatric Rehabilitation.

Wahyono. (2020, Maret 08). Sejumlah Kawasan Industri Besar di Indonesia. Retrieved from sindonews: https://ekbis.sindonews.com/berita/1548361/34/sejumlah-kawasanindustri-besar-di-indonesia/

Wuladani, W., Salamiah, Rizali, A., \& Suhartono, E. (2015). Dampak Kebisingan Terhadap Fungsi Pendengaran dan Tekanan Darah pada Pekerja Tyre di Workshop PT. Rahman Aabdijaya di Kabupaten Tabalong.

Yusuf, M. (2013). Pengaruh Kebisingan Terhadap Waktu Penyelesaian Pekerjaan Operator. Retrieved from https://publikasiilmiah.ums.ac.id/bitstream/handle/11617/3590/Paper\%20IENACO30.pdf?sequence=1\&isAllowed $=y$ 